\title{
Disabled people and accessibility: How successful is Slovenia in the elimination and prevention of built-environment and communication barriers?
}

The Urban Planning Institute of the Republic of Slovenia and the Institute of the Republic of Slovenia for Social Protection, together conducted a research project entitled 'Measures for the realisation of the rights of the disabled to barrier-free access' which was concluded in December 2008. The research was funded jointly by the Slovenian Research Agency and the Ministry of Labour, Family and Social Affairs. The main aim of the research was to conduct an extensive analysis of the state of care for persons with disabilities in Slovenia. This involved analysing the accessibility of the built environment and accessibility of communication and information, as well as investigating the efficiency of implementation of the policies and measures that were adopted at the national level for guaranteeing disabled persons barrier-free movement and social inclusion. The main part of the research is constituted of two field surveys, one conducted among individual disabled persons and the other conducted among the major disabled people's organisation in Slovenia. On the basis of a preliminary literature review and a review of the current legislation and policies concerning the disabled, the guiding hypothesis for the survey was that very little has been done, so far, towards the realisation of the rights of the disabled which are declared in the various national documents. The results of the empirical research provide evidence in support of this hypothesis. In this paper, we present the results of both field surveys, give a summary of the major findings and, in conclusion, suggest some measures that need to be implemented in order to ensure greater efficiency of the realisation of the rights of the disabled to barrier-free access.

Keywords: disable persons, built-environment barriers, communication barriers, barrier-free movement, accessibility, prevention and removal of barriers 


\section{Introduction}

Disability has, for some time now, been recognised as an important political issue, especially in connection with the guaranteeing of universal human rights. It is estimated that functionally impaired people account for 15 to $25 \%$ of the active population of Europe. According to the legally defined status of disability during the 2002 population census, there were just under 170,000 disabled persons at the time in Slovenia. In comparison with the total number of inhabitants, disabled persons thus accounted for $8.48 \%$ of the total population (Vertot, 2007). In spite of these relatively large numbers, disabled persons are, regrettably, often subjected to various forms of discrimination. Discrimination mostly takes the form of barriers in the built environment, barriers with regard to access to information and barriers to means of communication. The realisation of the rights of the disabled and facilitation of their active participation in society therefore, presents a major challenge worldwide.

As is the case with all other fields, policies for dealing with the problems of people with functional impairments in the built environment must be based on analyses of the societal situation in a given area at a given tine. Due to a growing awareness about these issues, it may be observed that there has been a noticeable increase in the number of researchers and other experts engaged in the field. The literature includes various sub-topics related to this theme. Some authors deal with the problems related to the planning and designing of the built environment (among them: Balchin and Rhoden, 1998; McGrail et al., 2001; Burns, 2004; Harrison, 2004; Bulos and Teymur, 1993; Thomas, 2004; Imrie, 2004a; Ellison and Burrows, 2007). Irrespective of their various approaches, the general argument put forward by these authors is that the planning and designing of the built environment must always take into account the regulations and standards prescribed for guaranteeing barrier-free access for the disabled. These authors stress the notion of 'inclusive design' or 'design for all' (Kervina et al., 2007), also referred to as 'universal design' (Sandhu et al., 2001; Internet 1). The so-called 'life-time homes' (Milner and Madigan, 2004; Barlow and Venables; Internet 2) are a concrete examples of such design concepts. Life-time homes are essentially living spaces that allow for functional adaptations of space and furniture to the needs of the user throughout their life period, whereby the costs of adaptation are minimum.

On the other hand, Harrison and Davis (2001) caution against the danger of spatial exclusion as a consequence of the modern approaches to the planning of specialised shelters for disabled people. They raise concerns about the use of the term 'special needs of the disabled' in spatial planning as this may result in the segregation of certain groups of people due to the application of special urban and architectural design regulations. The authors argue that such approaches can lead to the creation of 'disabled-people ghettos'. In order to avoid such undesirable occurrences, they suggest, as better approaches, the application of network concepts such as 'living support,' round the corner', and 'life-sharing.' The common characteristic of all these networks is that they provide support to the disabled in such a way that those providing the support live 'near by', 'round the corner'. The idea behind these approaches is that they enable disabled persons to live almost totally independently.

Other authors have focussed on technological and technical innovations intended for making easier the life of the disabled and improving their quality of living (for example: Peace and Holland, 2001; Brenton, 2001; Imrie, 2004b; Hanson, 2001; Fisk, 2001; Heywood, 2004; Kelly, 2001: Drewsbury et al., 2004). Here, investigations are conducted and presentations made of new solutions for guaranteeing disabled people optimum opportunities for independent living in a home of their choice, with the help of technological support. One of the innovations that have received particular attention recently is the 'smart home' (Pecora and Cesta, 2007; Zupan et al., 2007). Smart homes are equipped with the most modern installations, accessories and technological devices, which are mutually functionally connected, creating conditions that enable disabled persons the highest level of functional autonomy and independence. According to Ostrovršnik (2004), the smart home is essentially based on the concept of functionality, flexibility, safety, energy efficiency, comfort, high quality of living and, above all, the easiest accessibility possible which enables autonomy and independent living. In addition to smart homes, there are several other technological solutions in this area which are often referred to in the literature as 'assistive technologies'. Assistive technology is "an umbrella term for any device or system that allows an individual to perform a task that they would otherwise be unable to do or increase the ease and safety with which the task can be performed" (Cowan et al., 1999; quoted in: Drewsbury et al., 2004: 811). A more detailed presentation of some of the major assistive technologies has been given in the report of the research conducted on the realisation of the rights of the disabled in Slovenia (Sendi et al., 2008).

In Slovenia too, a similar increase in the amount of research projects and scientific expert publications has been observed. The publication edited by Kresal (2007) describes in detail the rights of the disabled in Slovenian by sector: education, employment and labour, health care and insurance, pension and disability insurance, parental care and family allowances, social care, tax relief, war disabled, disabled people organisations and claiming and protection of rights. 
Kukova et al. (2005) discuss the rights of people with intellectual disabilities, which they define as the category of disabled people that is discriminated against mostly. They analyse the rights of this category of the disabled with regard, particularly, to access to education and employment. Discrimination due to barriers in the built environment was also the topic of the doctorate degree thesis by Vodeb (2007). The thesis focuses on discrimination (especially of people with physical disabilities) with respect to access the living environment and public spaces.

The Institute of the Republic of Slovenia for Social Protection (IRSSP) plays a particularly important role in conducting research in the field of care for the disabled in Slovenia. Among the most important research projects that were conducted by the institute, are two studies by Nagode and Dremelj (2004, 2005), which present extensive analyses of the social support networks for people with mobility impairments in Slovenia. In addition to these, Kobal et al. (2006) conducted a study on social transfers, which investigated the funding of disabled people in Slovenia. As a basis for the preparation of the Act on equal opportunities for the disabled, another research was conducted on the same theme, which focussed on an analysis of the socio-economic situation of the disabled (Kobal et al., 2007). An important research in this area also, was the comparative analysis of the independent living of the disabled in selected countries in the European Union (Kobal et al., 2004). The purpose of the research was to investigate the notion of independent living of the disabled and the related systems of personal assistance in practice in Sweden, Great Britain, Germany, France, Netherlands and Slovakia. The final aim was to suggest possibilities for the introduction of the personal assistance service also in Slovenia.

\subsection{Major international documents concerning the rights of the disabled}

At the international level, the year 1993 may be considered as one of the major milestones in this area. This is the year when the UN General Assembly adopted, for the first time, Standard regulations for equal opportunities for the disabled. The other important milestone was the year 2001 when the UN General Assembly recommended the preparation of a Convention on the rights of the disabled. This historical document, which was adopted by the General Assembly in 2006, presents the first legally binding document of the United Nations in the area of disability. Its fundamental aim is to guarantee the realisation of human rights and the principle of equal opportunities and equal treatment as well as the prevention of discrimination against the disabled. The Convention recognises the importance of accessibility to the physical, social and economic environment and access to information and communication technologies in enabling the disabled to fully exploit and enjoy human rights and basic freedoms.

Within the European Union, the Amsterdam Treaty stands out as one of the most important documents concerning the disabled. With this document (Article 13), the European Commission adopted the human-rights-based approach as the basic principle for tackling and solving the problems of people with disabilities. This approach seeks to guarantee equal living opportunities for the disabled. The Treaty commits Member States to the long-term implementation of strategies for combating discrimination, promoting social integration and active participation, enhancing education, training, lifelong learning and employment opportunities, facilitating independent living and increasing availability and equality of care and assistive technologies (Internet 3).

For the implementation of this strategy the European Commission adopted a directive that prescribes the establishment of a common framework for equal treatment in employment and professional qualifications and prohibits any form of discrimination. This legally binding document explicitly forbids discrimination due to invalidity (Internet 4). Another important document adopted by the European Commission in this area is the European action plan 2004-2010: Equal opportunities for people with disabilities.

\subsection{Care for the disabled in Slovenia}

In Slovenia, the rights of people with disabilities (like those of other citizens) are guaranteed by Article 14 of the Constitution of the Republic of Slovenia which provides that "Every person shall be guaranteed equal human rights and fundamental freedoms irrespective of national origin, race, sex, language, religion, political or other conviction, material standing, birth, education, social status, invalidity or other personal circumstance. All persons shall be equal before the law" (Constitutional law on the amendment of Article 14 of the Constitution of the Republic of Slovenia, OGRS, No. 69/2004: 8461).

On the basis of various documents of the European Union (particularly the Amsterdam Treaty and European Action Plan), Slovenia adopted two important documents in this area, namely: National guidance for improving access to the built environment, information and communication for the disabled - Strategy Accessible Slovenia, and the Action programme for persons with disabilities 2007-2013. The contents of these documents as well as the policies and initiatives concerning the rights of persons with disabilities are presented in detail in the report of the research on the rights of the disabled in Slovenia (Sendi et al., 2008). Under preparatory 
procedure in this area are two new laws, namely: Act on equal opportunities for the disabled and Act on long-term care and long-term care insurance.

The Strategy Accessible Slovenia and Action programme for persons with disabilities 2007-2013 presented the backbone for the research on the rights of the disabled on which this paper is based. The Strategy seeks to implement the relevant provisions of Article 14 of the Constitution of the Republic of Slovenia which, in the chapter dealing with human rights and fundamental freedoms, guarantees equality of all persons before the law. The aims stated in the Strategy are premised on the recognition that care for the disabled presents one of the most sensitive and specific components of general social development and, especially, economic policy. The year 2025 is set in the Strategy as the deadline for the realisation of all the goals determined in it. The end of 2006 and 2007 were specified as deadlines for realising the first measures, which included, inter alia, the adaptation of taxis to enable easier use by disabled persons, provisions in public transport for blind people with guide dogs etc.

The Action programme for the persons with disabilities specifies in detail the main tasks of the policies concerning care for the disabled for the period 2007-2013, the concrete goals that need to be achieved in specific areas, as well as the major institutions that are responsible for the performance of the determined tasks. The main aims of the Action programme are (Ministry of Labour, Family and Social Affairs, 2006):

- To raise public awareness about the disabled, their contribution to general development, their rights, dignity and needs.

- All disabled persons shall have the right to choose freely and without discrimination where and how to live and shall be fully included and fully participate in community life.

- To guarantee disabled persons access to the built environment, transport, information and communication.

- To guarantee, on the basis of equal opportunities and without discrimination, an inclusive education system at all levels and life-long learning.

- To guarantee disabled persons access to work and employment without discrimination in the working environment that is open to disabled persons, inclusive and accessible.

- To guarantee disabled persons an appropriate living standard, financial support and social protection.

- To guarantee disabled persons efficient health care.

- To guarantee disabled persons inclusion in cultural activities and access to cultural goods on an equal basis.

- To guarantee disabled persons participation in sports and recreation activities.
- To guarantee disabled persons equal participation in religious and spiritual life in their communities.

- To enhance the operation of disabled people's organisations.

- To detect and prevent violence and discrimination against the disabled.

While the aims to be achieved are precisely specified the two documents mentioned above and numerous measures for achieving the aims identified, it may be argued that very little has been done, so far, for the realisation of the stated aims. The underlying hypothesis of the research on the realisation of the rights of the disabled was that inefficiency of implementation measures was, above all, the result of inconsistence or inadequate compliance or total non-compliance with the laws and other regulations concerning the rights of the disabled.

The main purpose of the research, therefore, was to investigate which additional measures need to be urgently adopted to facilitate greater efficiency of the realisation of the rights of the disabled to barrier-free access. The principle aims of the research were (Sendi et al., 2008):

- To identify the major barriers that people with disabilities encounter while exercising their rights to barrier-free access or while performing their daily functions.

- To present and disseminate examples of good practices based on an analysis of the policies and initiatives of the European Union and Slovenia concerning access to the built environment, communication and information.

- To propose, to decision makers, appropriate methodologies and tools for ensuring greater efficiency in the implementation of the rights of the disabled to barrier-free access.

The research consisted of four main part (ibid.):

- A review of the policies and initiatives of the European Union and Slovenia concerning accessibility of the built environment, communication and information.

- A review of the latest approaches to the removal of barriers in the areas of the built environment, communication and information.

- Empirical research an extensive survey conducted among people with disabilities and disabled people's organisations.

- Formulation of proposals of measures for the realisation of the rights of people with disabilities to barrier-free access.

In this paper, we present only the results of the empirical research and the proposals the realisation of the rights of people with disabilities to barrier-free access. 


\section{Empirical research}

\subsection{Research methodology}

The core of the research project is presented by two extensive field surveys, one conducted among individual disabled persons and the other among disabled people's organisations. The field surveys were conducted with the help of questionnaires, one for individual disabled persons and another for the representatives of disabled people's organisations. The aim of the survey was to identify concrete barriers in the built environment and communication barriers in Slovenia, which disabled persons encounter in their daily lives.

Barriers in the built environment were defined in the survey as those that include architectural and technical barriers (steep slopes, steps, kerbs etc.). These relate to the planning and construction of public and private buildings as well as the planning, development and maintenance of public and private space.

Communication barriers were defined as those that include the absence of interpreters, tactile information, induction loops, subtitles, computers and the Internet, verbal announcements, displays and the like. These relate to the systems for the transfer and exchanging of information as well as the systems for mass communication (radio, television, newspapers, the internet, etc.)

The questionnaire for individual disabled persons consisted of eight sections. The first section with introductory questions was followed by six sections with questions on barriers in the areas of: transportation; education, training and employment; health and social care; public administration services; services provided by cultural institutions; sport, recreation and tourism; while the last section was meant for gathering demographic and socio-economic information. The questionnaire for disabled people's organisations was substantially very similar to the questionnaire for individual disabled persons. The only difference between them was that the questions in the first section of the questionnaire for individual disabled persons related to their ability to perform specific activities and the remedies used to perform those activities, whereas the first section in the questionnaire for organisations was meant for gathering information on the system of organisation, membership, financing, activities, cooperation with members etc. The questionnaire for organisations, of course, did not have a section for demographic and socio-economic data.

In view of the fact that there are no publicly accessible records on disabled persons and the types of disability at the national level, we requested the National Council of Disabled Peoples'
Organisations of Slovenia and individual disabled people's organisation to assist us in conducting the survey among the individual disabled persons. Various disabled people's organisations enabled us to gain access to their members and also performed, on our behalf, some of the tasks during the survey exercise in accordance with the requirements for the protection of personal data. For the conducting of the survey among disabled people's organisations, 10 organisations were selected out of the 26 organisations operating at the national level (data from the Ministry of labour, family and social affairs). The criteria for selection of the organisations that participated in the survey were relevance of the main activities of the organisation to the subject of investigation in the survey (barriers in the built environment and communication barriers) and the characteristics of their members (type of disability):

- Društvo distrofikov Slovenije (The Slovene Association of persons with dystrophy)

- Zveza društev slepih in slabovidnih Slovenije (The Union of the Blind and Partially Sighted)

- Društvo larigektomiranih Slovenije (Association of the laryngectomised persons of Slovenia)

- Zveza društev gluhih in naglušnih Slovenije (The Union of the Deaf and Hard of hearing of Slovenia)

- Združenje multiple skleroze Slovenije (Slovenian Multiple Sclerosis Society)

- Društvo paralitikov Slovenije PARAS (The Slovene Association of Persons Suffering from Paralysis PARAS)

- Zveza paraplegikov Slovenije (The Union of the Paraplegics of Slovenia)

- Zveza Sonček Zveza društev za cereblarno paralizo Slovenije (SONČEK the Cerebral Palsy Association of Slovenia)

- Zveza Sožitje zveza društev za pomoč osebam z motnjami v duševnem razvoju Slovenije (The Union Sožitje The Union for helping people with mental development disorders)

- Društvo VITA za pomoč po nezgodni poškodbi glave (VITA Association for providing help after suffering head injuries).

The field survey was conducted in two stages, starting with the individual disabled persons, followed later on by the disabled people's organisation. In case of the first survey we asked the participating representative disabled people's organisations to pass on the questionnaires to their members (since we did not have their addresses due to personal data protection regulations). The organisations were advised to randomly select interviewees from their records taking into account only the condition that the total sample should consist of $50 \%$ of the interviewees from urban areas and 50\% from rural areas. In the event of a particular organisation being constituted of several regional or municipal affiliations, the questionnaires allocated 
to the organisation were distributed in equal numbers to all affiliates. The survey sample was determined with respect to the size of the organisation and the level of representation of disabled persons with specific types of disability. A total of 800 questionnaires for individual disabled persons were sent out.

The questionnaires for disabled people's organisations were sent to the representatives of the organisations (mostly the presidents) who also answered questions on the barriers encountered by their members in the built environment and in communication. Altogether, 116 questionnaires were sent to disabled people's organisations over the entire territory of Slovenia.

\subsection{Results of the empirical research}

\subsubsection{Information gathering and response to the survey}

By the end of the deadline set for the return of questionnaires sent to individual disabled persons (15 May 2008), only a small number of questionnaires had been returned. As such, we made telephone calls to all the disabled peoples to discuss with them the problems encountered and the reasons for the poor response. We asked the representatives of disabled people's organisations to offer help to their members in filling out the questionnaires, where such help was needed. We also had a meeting with the representatives of the Slovene Association of Persons with Dystrophy and the Union of the Blind and Partially Sighted and the individual disabled persons that participated in the survey were contacted by telephone requesting them to return the completed questionnaires. At the beginning of June 2008, we sent a request once again to the disabled people's organisations asking them to encourage their members to participate in the survey.

At the closing of the field survey, 181 questionnaires filled out by individual disabled persons were received, accounting for $22.6 \%$ of the total number of questionnaires sent. The highest level of response (46\%) was from the members of the Union of the Deaf and Hard of Hearing of Slovenia, which actively participated in the survey by encouraging and helping its members to fill out the questionnaire. The Union's help was particularly important and very useful in this case, since deaf people had great problems in understanding the questions and filling out the questionnaire, which was quite complex and lengthy. A slightly lower level of response (42\%) was obtained from the members of the Union of the Paraplegics of Slovenia. It was discovered during the processing of the survey results that this group of disabled persons returned the most completely filled out questionnaires. The lowest levels of response of were recorded among the members of the Union Sožitje - The Union for helping people with mental development disorders (11\%) and the Sonček - the Cerebral Palsy Association of Slovenia (10\%).

Several members of the disabled people's organisations who received the questionnaire contacted us also by telephone. Most of their comments concerned the complexity and length of the questionnaire while others expressed doubts about the usefulness of such surveys. The later were of the opinion that great improvement could be achieved simply through the consistent implementation of current regulations governing the subject under consideration.

After completing the survey of individual disabled persons, we started conducting the survey of the disabled people's organisations. At the end of June 2008, we sent to a selection of disabled people's organisations a questionnaire, accompanied by a brief explanation of the aims and goals of the survey together with a pre-postage paid return envelope. Enclosed too was a letter of support from the National Council of the Disabled People's Organisations of Slovenia. The questionnaire was made available also in an electronic form on our web site. During August and September, we sent a request to the organisations that had not responded by then, kindly asking them, once again, to participate in the survey. Several organisations declined to participate with the explanation that such surveys do not lead to any improvements for the disabled persons while others claimed they were too busy or occupied with other more important matters. At the end of September 2008, we decided to conclude the field survey.

The level of response of disabled people's organisations was slightly higher than that of individual disabled persons as 41 organisations returned the filled out questionnaires, accounting for $35.3 \%$ of the total survey sample. Some organisations (SONČEK, the Slovene association of persons with dystrophy and the Slovene association of persons suffering from paralysis) did not return any questionnaire, which indicates that they did not want to participate in the survey.

As in the case of the individual disabled persons' survey, the highest response in the survey of disabled people's organisations was received from the Union of the Deaf and Hard of Hearing of Slovenia (75\%). This indicates that the representatives of this organisations as well as its individual members are concerned about the improvement of the situation in this area (especially in the area of communications barriers). In addition to the high response their eagerness to participate in the survey was also manifested during the several discussions we had with them. Although the response of the disabled people's organisations was higher than that of the individuals we, nonetheless, do not consider such a level of response high enough. 
In view of the seriousness of the problem, we had expected a much higher level of response to the survey. The low level of response may be attributed to various factors namely:

- the sensitiveness of the issues under consideration and fear, on the part of the respondents, that the protection of personal date would not be guaranteed,

- inability of some categories of the disabled persons to independently fill out the questionnaire (especially people with mental disabilities and the blind),

- the (already mentioned) indifference of disabled people, especially the representatives of disabled people's organisations who are often asked to respond to various questionnaires, give their opinion and suggest solutions to problems while, in practice, the measures and solutions are not implemented effectively.

\subsubsection{Analysis of survey results}

In continuation, we present the results of both surveys. To facilitate easier comparison of the responses of the individual disabled persons with those of the representatives of disabled people's organisations, the most important results by area investigated are presented together in the tables. The tables show the built-environment and communication barriers that were identified as many barriers or a lot of barriers in the responses of the disabled persons and the representatives of organisations.

\section{Barriers in the area of passenger transport}

The area of passenger transportation included: city passenger transport, inter-regional passenger transport, taxis, railway transport, air transport and sea transport.

Generally, the number of representatives of disabled people's organisations that feel that disabled people in Slovenia experience many or a lot of barriers in passenger transport was higher than the number of individual disabled persons that expressed such levels of barriers in this area. Concretely, $41 \%$ of the representatives of disabled people's organisations indicated the presence of many or a lot of barriers in the built environment, communication barriers were indicated by $46 \%$ of this group of respondents, while the proportions of barriers indicated by individual disabled persons in this area were $30 \%$ and $32 \%$ respectively.

Both the individual disabled persons and the representatives of disabled people's organisations are of the opinion that the inter-regional bus transport and railway transport present the greatest problems with respect to built-environment barriers (Table 1). The representatives of disabled people's organisations find these two forms of transportation the most problematic also with regard to communication barriers, while the individual disabled persons identified also air transport as an area where they experience many or a lot of communication barriers. Taxis were identified as the most barrier free forms of transport by both groups of respondents. This is not so surprising since, in comparison with the other forms of passenger transport, taxis are the most individualised means of transportation which, on the other hand, usually offer a higher price service.

\section{The most important built-environment and communication barriers in the area of passenger transport}

Entrances into and exits out of passenger transport buildings as well as entrances and exits from various means of transportation present an important built-environment barrier to the disabled. According to the representatives of disabled people's organisations, passenger transport buildings should not have steps, different heights of access areas (kerbs) or narrow doors and passages. Regarding access to means of transport, they point out the need to distinguish between two different problems. One concerns poor accessibility in relation to the way a public transport station is constructed, the other relates to poor accessibility in terms of covering the distance to reach station. Both the representatives of disabled people's organisations and individual disabled persons identified as the most frequent communication barriers in passenger transport, audible signals, displays and inadequate signalling. The individual disabled persons also identified various problems in communi-

Table 1: The level of experience of built-environment and communications barriers identified by the respondents, as many barriers or a lot of barriers in the area of passenger transport.

\begin{tabular}{|c|c|c|c|c|}
\hline \multirow[t]{2}{*}{ Passenger transport } & \multicolumn{2}{|c|}{ Built-environment barriers (\%) } & \multicolumn{2}{|c|}{ Communications barriers (\%) } \\
\hline & Individuals & $\begin{array}{l}\text { Representatives of orga- } \\
\text { nisations }\end{array}$ & Individuals & $\begin{array}{l}\text { Representatives of organi- } \\
\text { sations }\end{array}$ \\
\hline City bus transport & 30.0 & 48.0 & 30.0 & 45.0 \\
\hline Inter-regional bus transport & 40.0 & 5.2 .0 & 37.0 & 48.0 \\
\hline Taxis & 18.0 & 26.0 & 24.0 & 44.0 \\
\hline Railway transport & 34.0 & 55.0 & 31.0 & 50.0 \\
\hline Air transport & 27.0 & 25.0 & 37.0 & 45.0 \\
\hline Sea transport & 27.0 & 32.0 & 35.0 & 42.0 \\
\hline
\end{tabular}


cation and obtaining information on transport schedules. Regarding this problem, the representatives of disabled people's organisations complained that information is not regularly updated, that traffic schedules are not clearly legible (very small print is a problem especially for the partially sighted) and so on.

Proposals for the removal of built-environment and communication barriers in the area of passenger transport

The proposals put forward by the respondents for the removal of built-environment barriers in the area of passenger traffic call for the introduction of measures to ease entry into and exit from the various means of transportation as well as the adaptation of public transport facilities to the needs of the disabled. The representatives of disabled people's organisations suggested the construction of gradients and lifts, lowering the height of steps and kerbs, placing benches at public transport stations, mounting wider doors on public transport vehicles and the use of low floor vehicles. They also suggested that there was a need to conduct an accurate investigation of the situation regarding built-environment and communication barriers and draw up a catalogue of the current accessibility of major public transport facilities. With regard to the removal of communication barriers, the respondents proposed the adaptation ticket-selling counters to the needs of the disabled and the erection of various warnings, notices and signs (audible signals, light displays etc.). Both the individual disabled persons and representatives of disabled people's organisations stressed the need to ensure consistent compliance with current legislation and regulations as well as the need to take into consideration the needs of the disabled and the correction of existing irregularities.

Responsibility for the implementation of measures for the elimination of built-environment and communication barriers in the area of passenger transport
The respondents were generally of the opinion that of the responsibility for the implementation of measures for the elimination of built-environment and communication barriers in the area of passenger transport lay, primarily, with state institutions. The individual disabled persons felt that government ministries, municipalities and local administration units carried the greatest responsibility for removal of both forms of barriers. The representatives of disabled people's organisations believe that these state institutions are especially responsible for the removal of communication barriers while, in their opinion, the removal of built-environment barriers in passenger transport is, above all, the responsibility of professionals (architects, physical planners, civil engineers, software experts etc.).

\section{Barriers in the area of education, training and employment}

Investigated under the area of education, training and employment were also kindergartens, primary and secondary schools, universities, organisers of various training courses, enterprises, providers of vocational and employment rehabilitation and the like.

The survey showed that individual disabled persons experienced slightly more built-environment barriers (one-third of the respondents) than communication barriers (28\%) in the area of education, training and employment. The percentage of representatives of disabled people's organisations who stated that disabled persons experience a lot of barriers in this area was higher than that of the individual respondents. The level of experience of built-environment barriers was indicated by more than $38 \%$ of the representatives of disabled people's organisations, while the presence of communication barriers in this area was felt by $54 \%$ of this group of respondents.

Individual disabled persons encounter many or a lot of builtenvironment barriers mostly in primary schools and in places where training courses are organised while they experience le-

Table 2: The level of experience of built-environment and communications barriers identified by the respondents as many barriers or a lot of barriers in the area of area of education, training and employment.

\begin{tabular}{llrr}
\hline Respondent & Institution/field & Built-environment barriers (\%) & Communication barriers (\%) \\
\hline & Kindergartens & 26.4 & 32.0 \\
\cline { 2 - 4 } & Primary schools & 39.6 & 30.4 \\
\cline { 2 - 4 } & Secondary schools & 35.2 & 25.0 \\
\cline { 2 - 4 } Individuals & Universities & 32.7 & 31.1 \\
\cline { 2 - 4 } & Open universities & 25.5 & 27.8 \\
\cline { 2 - 4 } & Training course organisers & 40.0 & 25.6 \\
\cline { 2 - 4 } & Providers of vocational and employment rehabilitation & 33.3 & 29.0 \\
\hline \multirow{2}{*}{ Representatives } & Services & 35.0 & 42.0 \\
\cline { 2 - 4 } & Education and training & 49.0 & 58.0 \\
\hline
\end{tabular}


ast built-environment barriers in kindergartens and with the providers of vocational and employment rehabilitation (Table 2). On the other hand, the representatives of disabled people's organisations were of the opinion that disabled persons experience most built-environment barriers in the area of employment and, to a lesser degree, in the area of education and training. Generally, the individual disabled persons indicated that they rarely experienced big communication barriers in the area of education, training and employment as compared to built-environment barriers. The representatives of disabled people's organisations expressed the opposite opinion in this regard who felt that disabled persons encounter many or a lot of communication barriers more frequently than built-environment barriers, particularly in the areas education and training and more so in employment.

The most important built-environment and communication barriers in the area of education, training and employment

The built-environment barriers most frequently mentioned by respondents in the area of education, training and employment were inappropriate accesses to buildings in which these activities are conducted as well as barriers inside the buildings such as steps, high thresholds, narrow doors, narrow passages, absence of lifts and absence of gradients. The representatives of disabled people's organisations were of the opinion that disabled people experience more barriers in this area of investigation especially in kindergartens and schools. They also pointed out the problem of school transport facilities that are not adapted to the needs of the disabled. The individual disabled persons also identified as a frequent barrier, inappropriate furniture in educational and employment institutions while the representatives of disabled people's organisations pointed out toilets that are inaccessible to the disabled (too narrow doors and toilet space for wheelchair users, toilets seats that are too high etc.). The communication barriers experienced by individual disabled persons in the area of education, training and employment were, above all, poor access to information, difficult communication, inappropriately adapted learning material and impatience and lack of solidarity on the part of fellow students. The representatives of disabled people's organisations stressed the problem of a lack of interpreters and the related expenses issues. According to the representatives of disabled people's organisations, deaf students would require the assistance of notes-takers during lectures while the hard of hearing would be greatly helped by the installation of induction loops in places where educational and employment processes are conducted. In addition to these, barriers were identified also concerning the transfer of information and knowledge (e.g., lecturers who are incomprehensible or talk too quietly), the shortage of adapted study literature and other learning material, reading difficulties (for example during lectures) and incomprehensible instructions for use of various devices.
Proposals for the removal of built-environment and communication barriers in the area of education, training and employment

For the removal of built-environment barriers in the area of education, training and employment, individual respondents suggest, as the most important measure, the introduction and implementation of appropriate legislation. They also proposed the adaptation of accesses to various buildings, to the needs of the disabled and to improve the functionality of buildings. Similar suggestions were made, to this effect, also by the representatives of disabled people's organisations. Both groups of respondents stated the same requirement that it is urgent to ensure close cooperation between the disabled and disabled people's organisations solutions on the one hand and architects and urban planners on the other hand, in the search for solutions for the removal of barriers in the current infrastructure and their prevention in new construction. The representatives of disabled people's organisations also stressed the need for financial support for the removal of built-environment barriers and the provision of tax relief on investments for these purposes.

For the removal of communication barriers in the area of education, training and employment, both groups of respondents suggested, in the first place, the regulation and efficient organisation of interpretation services. They also suggested the facilitation of long-distance education for disabled persons, the provision of basic communication remedies on state-financed prescription, the presentation of important matters in easily legible form (for example the use of large coloured letters and symbols), the positioning of information boards in locations that are accessible also to disabled persons using wheelchairs and to install induction loops in schools. According to individual disabled persons, communication barriers could be reduced also through the achievement of a higher level of tolerance of the general public, equality of the disabled, and willingness and readiness to offer help to those in need. They suggested that staff working in the area of education, training and employment need to be appropriately educated and provided with the skills required to work with disabled persons. The representatives of disabled people's organisations stated that there saw an urgent need to provide incentives for encouraging the employment of disabled persons and the need especially to "destigmatise" this area. Among the proposals put forward in this area is, once again, the proposal to conduct an accurate investigation of the situation regarding built-environment and communication barriers and, where these exist, notify those responsible for their removal.

Responsibility for the implementation of measures for the elimination of built-environment and communication barriers in the area of education, training and employment 
The majority of individual respondents believe that the responsibility for the removal of built-environment barriers in the area of education, training and employment lies, above all, with the relevant ministries while most of the representatives of disabled people's organisations felt that the professionals carry the greatest responsibility in this respect. With regard to communication barriers, both groups of respondents shared the same opinion that state institutions (governments, municipalities and public administration units) are most responsible for their removal.

\section{Barriers in the area of health and social care}

The investigation in the area of health and social care covered hospitals, health centres, outpatients' clinics, health resorts, social work centres and similar activities.

According to the responses of individual disabled persons, there are more built-environment barriers in this area (31\%) than there are communication barriers (18\%). The representatives of disabled people's organisations, on the other hand, indicated approximately the same levels (around 40\%) of experience with built-environment and communication barriers in the area of health and social care.

Amongst the institutions that provide health and social care services, the survey showed that individual disabled persons experience a lot of built-environment barriers especially in the social care centres. Social care centres were also identified as the institutions where disabled persons experienced the most communication barriers. It was also revealed by individual respondents that they experienced a lot of communication barriers even in safe houses and maternity homes at a level comparatively higher than the level of experience with built-environment barriers (Table 3). The levels of experience with barriers in the area of health and social care indicated by the representatives of disabled people's organisations were almost the same as those felt by the individuals in the case of built-environment barriers, and slightly higher in the case of communication barriers. According to the representatives of disabled people's organisation, the communication barriers were experienced mostly in health care institutions.

The most important built-environment and communication barriers in the area of health and social care

Regarding built-environment barriers in institutions which provide health and social care services, both individual disabled persons and the representatives of disabled people's organisations pointed as major built-environment barriers access to the buildings and to the rooms inside them (narrow corridors, lack of handles, absence of light displays, inappropriately contrasted signals etc.). It was also found that these institutions are often lack (adequate) suitably designed toilet facilities and some of the respondents complained about the diagnostic equipment that is not suitably adapted to the needs of the disabled. The respondents generally mentioned inappropriate and difficulties of mutual understanding with official personnel as the major communication barriers. To this effect, the individual disabled persons stressed especially the lack of empathy, kindness and patience on the part of the staff. Reference was made also to reception desks that are too high and glass counters as these make communication with personnel even more difficult. The representatives of disabled people's organisations pointed out also the difficulties of acquiring technical remedies for the deaf and hard of hearing, the absence of induction loops and shortage of interpreters.

Proposals for the removal of built-environment and communication barriers in the area of health and social care

For the removal of built-environment barriers in the area health and social care the respondents suggested, in the first place, the provision of suitable and properly functioning lifts, the provision of appropriate toilet facilities, the provision of proper access to buildings and increasing the number of parking places for the disabled. In addition to these measures, they suggested the adoption of appropriate legislation,

Table 3: The level of experience of built-environment and communications barriers identified by the respondents as many barriers or a lot of barriers in the area of area of health and social care.

\begin{tabular}{llrr}
\hline Respondent & Institution/field & Built-environment barriers (\%) & Communication barriers (\%) \\
\hline & Hospitals & 13.2 & 31.6 \\
\cline { 2 - 4 } & Health centres & 18.5 & 28.8 \\
\cline { 2 - 4 } Individuals & Outpatients' clinics & 15.5 & 26.1 \\
\cline { 2 - 4 } & Health resorts & 14.9 & 25.3 \\
\cline { 2 - 4 } & Social work centres & 35.9 & 41.5 \\
\cline { 2 - 4 } & Old people's homes & 11.6 & 32.6 \\
\cline { 2 - 4 } & Safe houses, maternity homes & 39.8 & 39.0 \\
\hline \multirow{2}{*}{ Representatives } & Health care & 40.0 & 44.0 \\
\cline { 2 - 4 } & Social care & 39.0 \\
\hline
\end{tabular}


ensuring consistent compliance with current legislation and tightening control and imposing stronger sanctions. They also suggested that the opinion of disabled persons should always be taken into account when searching for solutions to specific problems in this area. Given that most of the communication barriers identified in this area relate to communication with the official personnel, the respondents suggested as urgent, the employment of more suitably trained interpreters. The representatives of disabled people's organisations stressed also the need for providing general education and specific training for people working with the disabled. Other proposals in this area included: the installation of light signals and notices (displays), call for attendance in health centres by display, making appointments for seeing the doctor by phone texting, the provision of written information, the installation of induction loops and the provision of via internet web sites. The representatives of disabled people's organisations expressed once again the need to conduct an accurate investigation of the situation regarding built-environment and communication barriers and, where these exist, notify those responsible for their removal.

Responsibility for the implementation of measures for the elimination of built-environment and communication barriers in the area of health and social care

The respondents are of the opinion that state institutions (ministries and public administration units) carry the greatest responsibility for the implementation of measures for the removal of built-environment and communication barriers in the area of health and social care. In addition to these, professionals and the providers of services were also identified by a large percentage of respondents as highly responsible for the elimination of both types of barriers in this area.

\section{Barriers in the area of public administration services}

The public administration services covered by the survey included: municipalities, public administration units, courts, tax offices, employment offices, pension and disability insurance offices, health insurance offices and other similar institutions.
The percentage of respondents that stated that they experienced many or a lot of built-environment barriers was just slightly less than that of communication barriers experienced in this area ( 41 and 54\% respectively). This indicates a level of experience with barriers that is comparable to that found in the area of passenger transport. The percentage of representatives of disabled people's organisations that indicated the presence of either type of barrier in the area of access to public services was higher than that of individual respondents. More than $50 \%$ of this group of respondents were of the opinion that their members experience quite a lot of built-environment and communication barriers in this area.

It was found that the individual disabled persons experience the most built-environment barriers in relation to access to judicial authorities, while municipalities presented the second biggest barrier. Courts were also identified by individual respondents as institutions where they experienced the most communication barriers in this area. Tax offices and employment departments were also pointed out as institutions where the disabled experience many communication barriers (Table 4). The representatives of disabled people's organisations were of the opinion that their members often experienced communication barriers in the area of access to public administration services.

The most important built-environment and communication barriers in the area of public administration services

The most frequent built-environment barriers identified in the area of access to public administration services were inaccessibility of buildings and specific areas inside them (narrow doors, high thresholds, steps, absence of lifts etc.). According to the representatives of disabled people's organisations, older buildings, in particular, present most of the built-environment barriers in this area. The respondents also pointed out as major barriers, inappropriately designed and inaccessible toilet facilities as well as inadequate parking spaces for the disabled in front of public administration institutions. Regarding com-

Table 4: The level of experience of built-environment and communications barriers identified by the respondents as many barriers or a lot of barriers in the area of access to public administration services.

\begin{tabular}{llrr}
\hline Respondent & Institution/field & Built-environment barriers (\%) & Communication barriers (\%) \\
\hline & Municipalities & 45.5 & 43.3 \\
\cline { 2 - 4 } & Public administration units & 42.9 & 42.1 \\
\cline { 2 - 4 } Individuals & Courts & 50.0 & 50.6 \\
\cline { 2 - 4 } & Tax offices & 42.0 & 47.5 \\
\cline { 2 - 4 } & Employment office departments & 39.7 & 47.9 \\
\cline { 2 - 4 } & Pension and disability insurance depart- & 34.1 & 43.3 \\
\cline { 2 - 4 } & ments & 30.2 & 39.8 \\
\hline Health insurance departments & 51.0 & 53.0 \\
\hline
\end{tabular}


munication barriers, the respondents identified several barriers including: problems with the availability of interpreters (uneven regional coverage with interpreters and their shortage especially in courts), the need to increase the use special technical equipment (larger writing on notices and various administrative forms, increased use of audible signals, subtitles and similar technologies), problems concerning informing and notifying the disabled, problems with forms and instructions for filling them out which are often written in a complex and incomprehensible manner and problems of communication with personnel (contact counters that are often dark, too high with bells often placed at inappropriately high positions). The individual disabled respondents also complained about the unkindness of the official personnel.

Proposals for the removal of built-environment and communication barriers in the area of public administration services

For the removal of built-environment barriers in this area, individual respondents suggested the amendment of existing legislation and its harmonisation with EU legislation. They also suggested the adaptation of existing buildings to the needs of the disabled and the provision of more funds for the removal of architectural barriers (for example the installation of lifts). They stressed the importance of consultation between building contractors and the disabled (the users) when undertaking this work. Most frequently mentioned among the proposal put forward for the removal of communication barriers in this area, was the need to provide interpreters in all public administration offices. The individual respondents stressed that they longed for more tolerance, kindness and cultured manners of communication with official personnel. According to the representatives of disabled people's organisations, the removal of built-environment and communication barriers in the area of public administration services will be possible only on condition that existing legislation, regulations and strategies are fully complied with, while at the same time imposing suitable sanctions on those who fail to comply. They are also of the opinion that there is a need to gather the views of the disabled and organise educational programmes, informative courses for official personnel about the different forms of disability and the specific needs of people with disabilities. Also in this case the representatives of disabled people's organisations suggested the inventorisation of the situation regarding builtenvironment and communication barriers and, where these exist, the notification of those responsible for their removal.

Responsibility for the implementation of measures for the elimination of built-environment and communication barriers in the area of public administration services

The respondents were, logically, certain that the service providers (ministries, municipalities, public administration units, courts, tax offices, etc.) carry the greatest responsibility for the implementation of measures for the removal of built-environment and communication barriers in this area. They also felt, however, that a high degree of responsibility lays with the professionals, i.e., architects, civil engineers, spatial planners, software designers etc.

\section{Barriers in the area of cultural institutions}

The investigation under this area covered institutions such as: theatres, museums, galleries, cultural centres, concert halls, libraries, cinemas and similar institutions.

The results of the survey gave the same percentages for builtenvironment and communication barriers (39\% in either case) that were experienced as many or a lot of barriers by individual disabled persons. The representatives of disabled people's organisations, on the other hand, indicated comparatively higher levels of experience of built-environment barriers $(45 \%)$ and also higher levels of communication barriers (48\%).

According to the individual respondents, they experience most built-environment barriers in museums, while cinemas were identified as places where they experience least barriers (Table 5). With respect to communication barriers, concert halls were found to present the most barriers for the individual respondents, as were cultural centres, galleries and theatres.

Table 5: The level of experience of built-environment and communications barriers identified by the respondents as many barriers or a lot of barriers in the area of cultural institutions.

\begin{tabular}{llll}
\hline Respondent & Institution/field & Built-environment barriers (\%) & Communication barriers (\%) \\
\hline & Theatres & 40.1 & 40.0 \\
\cline { 2 - 4 } Individuals & Museums & 50.7 & 37.6 \\
\cline { 2 - 4 } & Galleries & 40.0 & 40.7 \\
\cline { 2 - 4 } & Cultural centres & 41.1 & 41.2 \\
\cline { 2 - 4 } & Concert halls & 42.6 & 34.6 \\
\cline { 2 - 4 } & Libraries & 34.2 & 37.5 \\
\cline { 2 - 4 } & Cinemas & 25.9 & 48.0 \\
\hline Representatives & Access to cultural institutions services & 45.0 & 48.0 \\
\hline
\end{tabular}


Libraries were indicated as institutions with the least communication barriers.

The most important built-environment and communication barriers in the area of cultural institutions

The survey showed that both groups of respondents indicated as the most frequent built-environment barriers in this area inaccessibility of buildings and area inside them (steps, absence of lifts, absence of gradients or gradients that are too steep, narrow entrances and passages, and heavy doors). Reference was also made to toilet facilities and cloakrooms that are not suitable for the use of the disabled. Other barriers identified in this area include a shortage of parking spaces for the disabled in front of cultural institutions and inaccessible driveways to the buildings. In the case of communication barriers, difficulties in relation to communication with employed staff were the barrier most frequently stated by the individual respondents. Museums, galleries, theatres and the opera were identified as the most problematic institutions in this regard. The respondents indicated that they also experience considerable barriers at reception desks, glass counters and ticket selling booths that are often positioned too high for some types of disability. Reference was also made to barriers in connection with waiting in long cues, small subtitles in cinemas, paintings that are hung too high in galleries and inappropriate sound systems. In addition to these, the representatives of disabled people's organisations mentioned also notices in small print, small signs, small print in cultural institution handouts, lack of information in easily legible writing, non-qualitative methods of information and inability to provide constantly updated information. Both groups of respondents pointed out the considerable shortage of interpreters and the absence of induction loops in places and halls where cultural events are organised.

Proposals for the removal of built-environment and communication barriers in the area of cultural institutions

For the removal of built-environment barriers in this area, the respondents proposed, in the first place, the adaptation to the needs of disabled persons and improvement of accesses to the facilities providing cultural services. The measures proposed include: the construction of gradients, escalators and lift, the construction of staircases with railings, the lowering or removal of thresholds, the lowering of pavement heights, the construction of wider doors and provision of suitable and adequate parking facilities. They also propose the provision of suitable toilet facilities and the representatives of disabled people's organisations suggested also the construction of relief floor signs inside buildings providing cultural services. The individual respondents proposed the introduction of legislation especially in the area of new construction and the provision of the fun- ding required to achieve improvements in this area. They stress the need for strict controls and the imposition of sanctions on those who violate the relevant legal provisions. Regarding the removal of communication barriers the representatives of disabled people's organisations proposed the introduction of special counters or service areas for people with disabilities. Other suggestion put forward by the representatives of disabled people's organisations included the creation of special internet web sites providing information for the disabled, the provision of written information with pictures, the provision of information in Braille and audible forms and the requirement that all projections are accompanied by subtitles. Both groups of respondents stressed the need to provide interpreters (for deaf persons) and the installation of induction loops for the hard of hearing. Individual respondents expressed the wish that their views as well as the views of their representative organisations are more regularly considered. The representatives of disabled people's organisations, on the other hand, would like to see that current legislation, regulations and strategies concerning this area are consistently complied with. It was also suggested that special tax incentives should be provided in the case of investments intended for the removal of built-environment and communication barriers in this area. As in the case of all other areas already presented, the representatives of disabled people's organisations suggested also in this area the inventorisation of the situation regarding built-environment and communication barriers and, where these exist, the notification of those responsible with the demand that the barriers are removed promptly. It was also stressed here that the views of the disabled should be taken into account when executing measures for the removal of the barriers found.

Responsibility for the implementation of measures for the elimination of built-environment and communication barriers in the area of cultural institutions

The respondents were of the opinion that the responsibility for the implementation of measures for the removal of barriers in this area lies, above all, in the hands of state institutions (ministries, municipalities and public administration units), followed by the providers of services and professionals. In this, the professionals were charged with greater responsibility for the implementation of measures for the removal of built-environment barriers and less for communication barriers.

\section{Barriers in the area of sport, recreation and tourism}

The investigation in this area included, among others: gyms, open-air sports facilities, swimming pools, accommodation facilities for tourist purposes (rooms, apartments, bungalows etc.), catering facilities (restaurants, inns, bars, night clubs etc.). 
The individual respondents indicated that they experience more built-environment barriers (35.2\%) in comparison with communication barrier (26.2\%). The representatives of disabled people's organisations, on the other hand, indicated the opposite. According to their responses, disabled people experience more communication barriers (58.8\%) as compared to the level of experience with built-environment barriers (40\%).

Most of the individual respondents identified swimming pools as the facilities where most built-environment barriers are experienced. Similar levels of presence of built-environment barriers were indicated also for catering facilities and tourist accommodation facilities while the open-air sports facilities were found to be the least problematic (Table 6). The latter were identified as the least problematic also with regard to communication barriers whereas gyms and catering facilities were indicated as the places where most communication barriers were experienced. The representatives of disabled people's organisations, on the other hand, were of the opinion that disabled people generally encounter both built-environment and communication barriers at approximately the same levels in sport and tourism facilities.

The most important built-environment and communication barriers in the area of sport, recreation and tourism

The most problematic built-environment barriers identified by the respondents in the area of sport, recreation and tourism were steps, high kerbs, narrow doors, toilet facilities not suitable for use by disabled persons, inappropriately designed paths, narrow passages and difficult access to swimming pools and narrow changing rooms which are, in most cases, not adapted to the needs of disabled persons. Individual respondents also mentioned built-environment barriers in catering facilities which are mostly accessible only during the summer when these organise open-air settings. They also experience barriers in accommodation facilities, in the use of ski-lifts at ski resorts (they are often too fast) and inaccessible spectator stands in sports facilities. With regard to communication barriers, the most frequently mentioned barriers in the area of sport, recreation and tourism were communication with the employed staff, absence of interpreters, inadequate instructions, signs and subtitles which are often also too small. Noise in halls and other places where large masses of people gather was also pointed out as a major barrier which makes difficult communication with others and, in the process, often draw to themselves the attention of those around them. Mentioned too, in this respect, was poor signalisation and poor lighting of certain spaces inside facilities. They also complained about a lack of understanding, of the situation of disabled persons, on the part of the employed staff who are in their opinion not tolerant enough, disrespectful and not qualified for work with the disabled. The representatives of disabled people's organisations pointed out especially the problem of inadequacy of tourism offers suitable for the needs of the disabled, coupled with the fact that tourist guides usually do not know sign language.

Proposals for the removal of built-environment and communication barriers in the area of sport, recreation and tourism

For the removal of built-environment barriers in the area of sport, recreation and tourism, most of the respondents suggested the replacement of steps with gradients and lifts and many felt there was a need to revise the legislation concerning, especially, new construction. Some respondents pointed out the need to adapt pavements, walkways and cycle ways to the needs of the disabled, to provide rooms in hotels and holiday resort facilities suitable for the use of the disabled and to adapt the terrain and entrances to the needs of people with disabilities. Other proposals included the provision of more funds for the removal of barriers in this area, taking into consideration the views of the disabled, raising awareness and compliance with the official standards. The representatives of disabled people's organisations suggested the appropriate planning of parks, playgrounds, gyms and pathways, the construction of additional changing rooms adapted to the needs of disabled, the installation of lifts, the construction of gradients, the provision of railings in swimming pools and the construction of

Table 6: The level of experience of built-environment and communications barriers identified by the respondents as many barriers or a lot of barriers in the area of sport, recreation and tourism .

\begin{tabular}{llrr}
\hline Respondent & Institution/field & Built-environment barriers (\%) & Communication barriers (\%) \\
\hline & Gyms & 29.0 & 33.8 \\
\cline { 2 - 4 } & Open-air sport facilities & 18.8 & 16.6 \\
\cline { 2 - 4 } Individuals & Swimming pools & 43.4 & 24.2 \\
\cline { 2 - 4 } & Accommodation facilities for tourist pur- & 40.2 & 22.8 \\
\cline { 2 - 4 } & poses & 41.0 & 31.3 \\
\hline \multirow{2}{*}{ Representatives } & Catering facilities & 41.0 & 58.0 \\
\hline & Provision of sport and recreation activities & 43.0 & 59.0 \\
\hline
\end{tabular}


lifts in stadiums and in catering facilities. They also proposed that the number of personal assistants should be increased. With regard to the removal of communication barriers in this area, the representatives of disabled people's organisations would like to see improvements in access to information, while the individual respondents suggested the provision of interpreters. Generally, the respondents feel that disabled persons with various forms of disability ought to be asked about their concrete needs and that the views of the experts and disabled people's organisations also ought to be taken into account. As in previous cases, the investigation of the situation on the ground was suggested also in this case.

Responsibility for the implementation of measures for the elimination of built-environment and communication barriers in the area of sport, recreation and tourism

According to the majority of the respondents, the responsibility for the implementation of measures for the removal of barriers in this area was with the professionals, institutions and providers of services, in that order. Regarding the removal of built-environment barriers, the respondents stated that it was the professionals (architects, spatial planners, civil engineers, etc.) who carried the greatest responsibility.

\section{Major findings and conclusion}

The research revealed that very little has been done so far in Slovenia regarding the realisation of the rights of the disabled stipulated in various national and international documents. Disabled persons continue to encounter numerous barriers in the built and communication environments. A comparative analysis of the responses of individual disabled persons with those of the representatives of their organisations shows that the responses regarding the barriers identified are very similar. This is an indication that the representatives of disabled people's organisations have accurate knowledge about the barriers experienced by their members which, of course, is to be expected of them. This also means that barriers do exist and that they present a serious and general problem for people with disabilities.

With respect to barriers in the built environment, steps almost always pointed out as the biggest barrier encountered in the various areas investigated in the survey. These were followed in the second place by the absence of gradients or, in some cases, that these were too steep. The other barriers identified in this area were, in order of frequency: high kerbs and pavements, lifts frequently out of order, the absence of handles or railings, narrow doors or passages, inappropriately designed and, for disabled persons, inaccessible public toilets, etc. It is also important o note that the barriers identified in the built environment were more or less the same in all areas covered by the survey.

The situation is, however, different in the case of communication barriers. The barriers identified by the respondents differ according to the different areas investigated. It is, nonetheless, possible to make a summary of the communication barriers most frequently identified. On the one hand, individual disabled persons as well as the representatives of their organisations frequently mentioned the improper or difficult communication with employed staff and, on the other hand, unkindness and a lack of understanding of the problems of disabled persons on the part of the general public. Huge barriers are presented also by information systems which, in the majority of case, are inappropriate for the needs of disabled persons. The barriers most frequently identified in this regard were: illegible notices, inadequate instructions, absence of signs, inadequate signalling, poor lighting, poor quality sound systems, inappropriately located information desks etc. The absence of interpreters was often mentioned as an especially huge barrier for deaf people and those hard of hearing.

The respondents suggested a number of useful solutions for the removal of built environment and communication barriers, although these differ between themselves according to the various areas investigated. Several of the solutions suggested were already included in the Strategy Accessible Slovenia or in the Action programme for the disabled 2007-2013. This provides evidence that the authors of these documents covered well the concrete needs of the disabled. It is, however important to note that the respondents identified numerous barriers which ought to have been already removed already, in accordance with the policies and measures adopted in the national documents. Inconsistency and inadequate compliance or total incompliance with legal requirements and other regulations concerning the rights of the disabled are, therefore, the main reasons for failure to realise the rights of disabled persons to free-movement.

As such, the respondents in both categories stressed compliance with legislative provisions, greater supervision over their implementation and the need for the introduction of the necessary changes, as the most urgent measures that need to be taken in order to achieve improvements in the area of passenger transportation. The representatives of disabled people's organisations proposed that an exhaustive field investigation should be carried out for the purpose of identifying and drawing up an accurate record of all existing barriers in public buildings and public facilities. The individual respondents also suggested, in this area, that planners, investors and constructors ought to 
consult the disabled people before introducing new solutions in passenger traffic.

In the area of education, training and employment, the respondents expressed the need to introduce the necessary changes to the existing legislation as well as greater supervision over the implementation of the relevant legal provisions. The need to provide greater financial support was also stressed. Financial support is required especially for the implementation of measures for the removal of the major barriers identified and improvement of accessibility in this area as well as for the provision of tax relief for development programmes intended for the removal of barriers. While the disabled people's organisations suggest, in the area of communication, mainly technical measures and solutions, the disabled people's proposals stressed mostly the need for improving public awareness, greater tolerance, equality, more kindness and preparedness to provide help to others, in both educational and working environments. The disabled people's organisations also pointed out the need for the de-stigmatisation of the disabled in the area of education, training and employment.

The need for the consistent implementation of the relevant legislation was stressed also in the area of health and social care. The built barriers in this area concern especially inappropriate accesses (very steep gradients), malfunctioning lifts (lifts that are frequently out of order due to inadequate maintenance), problems in relation to driveways (parking space reserved for the disabled is often occupied by other vehicles) etc. As in the case of education and employment, disabled people long for more kindness and patience in communication with the staff employed in health and social care institutions. They would also like to have greater personal contacts with the staff.

Regarding access to public administration services, the representatives of the disabled proposed, among other things, the transfer of offices to locations that are more accessible to the disabled. And once again, both groups of respondents stressed the need to ensure that existing legislation is complied with and suitably implemented. In this case too, the representatives of disabled people's organisations suggested the identification of all existing barriers in this area and take appropriate action for their removal.

The solutions suggested in the survey for the removal of barriers that hinder access to services provided by cultural institutions are more or less the same as those already listed for the different areas above. With respect to communication barriers in this area, both groups of respondents stressed the need to increase the number of interpreters, the installation of induction loops, the provision of information in Braille and subtitling theatre performances.
In the area of sport and recreation, the representatives of the disabled people's organisations put forward considerably more proposals for improving access, than the individual respondents. Most of the proposals concern improvements at gyms, swimming pools and stadia where there is a need to ensure that entrances, doors, passages, lifts, gradients handles, toilets and changing rooms are planned in such a way as allows free access for disabled persons. The same applies also to catering facilities and all other places of entertainment. It was also pointed out in this section that hotels should include in their offer capacities that meet the requirements of disabled people.

Both groups of respondents are emphatic that the responsibility for the removal of barriers (built and communication) must be carried, above all, by state institutions (government ministries and municipalities and their public administration units). The second most frequently identified subject regarding the responsibility for the occurrence and removal of barriers were the experts (architects, spatial planners, civil engineers etc.), followed in the third place by the providers of the various services in the areas investigated. The order of responsibility continues with the disabled people's organisations in the fourth place while the disabled people themselves and their close relatives were stated as the least responsible for the removal of barriers.

The research has two major findings. First, the laws and regulations concerning the removal of existing barriers or prevention of the occurrence of new barriers are poorly or inadequately implemented in practice. Second, most of the measures listed in various national policy documents for the removal of barriers and facilitation of barrier-free movement have not yet been implemented. These findings therefore provide confirmation of the working hypothesis stated at the beginning of the research, i.e., little has been achieved so far in Slovenia in the implementation of the rights of the disabled that are declared in various documents concerning their full integrating and equal participation in society. The consistent compliance with the provisions of the relevant laws and regulations is a precondition for the transformation from paper to practice, of the measures determined for the removal or prevention of barriers. There is, therefore, an urgent need to go a step further from simply adopting legislation and determining measures for improving the situation. The proposal for the additional measure required to facilitate greater efficiency in solving the problems identified was given by the respondents themselves, more concretely, the representatives of disabled people's organisations. They suggested conducting a detailed field investigation in order to identify and systematically register all existing barriers in the major public buildings and public facilities and confront these with the various bodies or institutions responsible for the specific barrier, with the demand that the barriers are removed 
promptly. We consider this proposal a key mechanism which will finally lead to the actual execution of concrete measures for the realisation of the rights of the disabled to barrier-free access. This proposal presents the premise for the continuation of work on this research project.

Dr. Richard Sendi, Architect, Research Councillor

Urban Planning Institute of the Republic of Slovenia, Ljubljana,

Slovenia

E-mail: richard.sendi@uirs.si

Dr. Boštjan Kerbler - Kefo, Geographer, Assistant

Urban Planning Institute of the Republic of Slovenia, Ljubljana,

Slovenia

E-mail: bostjan.kerbler@uirs.si

\section{References}

Balchin, P., and Rhoden, M. (eds.) (1998) Housing: The essential foundations. London, Routledge.

Barlow, J., and Venables, T. (2004) Will technological innovation create the true lifetime home? Housing Studies, 19(5), pp. 795-810.

Brenton, M. (2001) Older people's cohousing communities. In: Peace, M. S., and Holland, C. (eds.): Inclusive housing in an ageing society. Innovative approaches, pp. 169-188. Bristol, The Policy Press.

Bulos, M., and Teymur, N. (eds.) (1993) Housing: Design, research, education. Aldershot, Avebury.

Burns, N. (2004) Negotiating difference: Disabled people's experiences of housebuilders. Housing Studies, 19(5), pp. 765-780.

Commission of the European Communities (2000) Towards a barrier free Europe for people with disabilities. COM (2000) $284 \mathrm{fi}$ nal. Available at: http://eur-lex.europa.eu/LexUriServ/LexUriServ. do?uri=com:2000:0284:fin:en:pdf (Date accessed 15. 4. 2009).

Commission of the European Communities (2003) EU disability action plan. First phase 2004-2005. COM(2003) 650 final. Available at: http://ec.europa.eu/employment_social/news/2003/oct/en.pdf (Date accessed 15. 4. 2009)

Constitutional law on the amendment of Article 14 of the Constitution of the Republic of Slovenia. Official Gazette of the Republic of Slovenia, No. 69/2004. Ljubljana.

Dewsbury, G., Rouncefield, M., Clarke, K., and Sommerville, I. (2004) Depending on digital design: Extending inclusivity. Housing Studies, 19(5), pp. 811-825.

Ellison, N., and Burrows, R. (2007) New spaces of (dis)engagement? Social politics, urban technologies and the rezoning of the city. Housing Studies, 22(3), pp. 295-312.

Fisk, M. J. (2001) The implication of smart home technologies. In: Peace, M. S., and Holland, C. (eds.) Inclusive housing in an ageing society. Innovative approaches, pp. 101-124. Bristol, The Policy Press.

Hanson, J. (2001) From special needs to lifestyle choices. In: Peace, M. S., and Holland, C. (eds.) Inclusive housing in an ageing society. Innovative approaches, pp. 29-52. Bristol, The Policy Press.
Harrison, M., and Davis C. (2001) Housing, social policy and difference: Disability, ethnicity, gender and housing. Bristol, The policy Press.

Harrison, M. (2004) Defining housing quality and environment: Disability, standards and social factors. Housing Studies, 19(5), pp. 691-708.

Heywood, F. (2004) Understanding needs: A starting point for quality. Housing Studies, 19(5), pp. 685-690.

Imrie, R. (2004a) Disability, embodiment and the meaning of home. Housing Studies, 19(5), pp. 745-763.

Imrie, R. (2004b) Housing quality, disability and domesticity. Housing Studies, 19(5), pp. 685-690.

Internet 1: www.design.ncsu.edu/cud/about_ud/udprinciplestext. htm (Date accessed 14. 8. 2008).

Internet 2: http://www.warrington.gov.uk/Housing/Privatehousing/ lifetime_homes_standard.aspx (Date accessed 14. 8. 2008).

Internet 3: http://www.svz.gov.si/fileadmin/svz.gov.si/pageuploads/ Primarna_zakonodaja/Amsterdamska.pdf (Date accessed 14. 8. 2008).

Internet 4: http://eur-lex.europa.eu/LexUriServ/LexUriServ.do?uri=D D:05:04:32000L0078:SL:PDF (Date accessed 14. 8. 2008).

Kelly, M. (2001) Lifetime homes. In: Peace, M. S., and Holland, C. (eds.) Inclusive housing in an ageing society. Innovative approaches, pp. 55-75. Bristol, The Policy Press.

Kobal, B., Tjaša, Ž., and Smole, S. (2004) Neodvisno življenje invalidov $v$ izbranih državah evropske unije. Ljubljana, Inštitut Republike Slovenije za socialno varstvo.

Kobal, B., Dremelj, P., Nagode, M., and Smolej, S. (2006) Analiza transferjev za invalide. Ljubljana, Inštitut Republike Slovenije za socialno varstvo.

Kobal, B. Dremelj, P., and Nagode, M. (2007) Analiza socialno ekonomskega položaja invalidov za pripravo Zakona o izenačevanju možnosti invalidov. Ljubljana, Inštitut Republike Slovenije za socialno varstvo.

Kervina, D., Pustinšek, M., in Bešter, J. (2007) Informacijske in komunikacijske tehnologije za e-vključenost. In: Hočevar, F. (ed.) Praktični vidiki in možnosti e-vključenosti in dostopnosti za invalide, starejše in za osebe z manjšimi možnostmi, pp. 13-21. Ljubljana, Inštitut Republike Slovenije za rehabilitacijo.

Kresal, B. (ed.) (2007) Vodnik po pravicah invalidov v slovenski zakonodaji. Ljubljana, Inštitut za delo pri Pravni fakulteti.

Kukova, S., Zaviršek, D., and Urh, Š. (2005) Rights of people with intellectual disabilities. Access to education and employment: Slovenia (monitoring report). Budapest, New York, Open Society Institute.

McGrail, B., Percivel, J., and Foster, K. (2001) Integrated segregation? In: Peace, M. S., and Holland, C. (eds.) Inclusive housing in an ageing society. Innovative approaches, pp. 147-168. Bristol, The Policy Press.

Milner, J., and Madigan, R. (2004) Regulation and innovation: Rethinking inclusive housing design. Housing Studies, 19(5), pp. 727-744. 
Ministry of Labour, Family and Social Affairs (2006) Action programme for persons with disabilities 2007-2013. Available at: http:// www.mddsz.gov.si/fileadmin/mddsz.gov.si/pageuploads/dokumenti_pdf/api_07_13_en.pdf (Date accessed 15. 4. 2009).

Nagode, M., in Dremelj, P. (2005) Spolne razlike v omrežjih socialne opore za ljudi z gibalnimi težavami s Sloveniji. Socialno delo, 44(1-2), pp. 117-123.

Nagode, M., in Dremelj, P. (2004) Omrežja socialne opore oseb z gibalnimi težavami. In: Novak, M. (ed.): Omrežja socialne opore prebivalstva Slovenije, pp. 121-129. Ljubljana, Inštitut Republike Slovenije za socialno varstvo.

Ostrovršnik, B. (2004) Pametna hiša kot orodje in priložnost za lažjo komunikacijo ljudi z omejenimi sposobnostmi z različnimi okolji. In: Bešter, J., and Humar, I. (eds.) Pametne stavbe, pp. 111-113. Ljubljana, Elektrotehniška zveza Slovenije.

Peace, M. S., and Holland, C. (eds.) (2001) Inclusive housing in an ageing society. Innovative approaches. Bristol, The Policy Press.

Pecora, F., and Cesta, A. (2007) DCOP for smart homes: a case study. Computational Inelligence, 23(4), pp. 395-419.

Sandhu, J. S., Saarnio, I., and Wiman, R. (2001) Information and communication technologies and disability in developing counties. Available at: http://siteresources.worldbank.org/DISABILITY/Resources/280658-1172609480904/InformationCommSandhu.pdf (Date accessed: 14. 8. 2008).

Sendi, R., Černič Mali, B., Kerbler, B., Kobal, B., Smolej, S., Nagode, M. et al. (2008) Ukrepi za uresničevanje pravic invalidov do dostopa brez ovir. Ljubljana, Urbanistični inštitut Republike Slovenije.

National guidelines to improve built environment, information and communications accessibility for people with disabilities. Official Gazette of the Republic of Slovenia, No. 113/2005. Ljubljana.

Thomas, P. (2004) The experience of disabled people as customers in the owner occupation market. Housing Studies 19(5), pp. 781-794.

Vertot, P. (ed.) (2007) Invalidi in druge osebe s posebnimi potrebami v Sloveniji. Ljubljana, Statistični urad Republike Slovenije.

Vodeb, V. (2007) Diskriminacija zaradi nedostopno grajenega okolja: analiza nedostopnosti z metodami geomatike. Ph.D. Thesis. Ljubljana, Univerza v Ljubljani Fakulteta za arhitekturo.

Zupan, A. Cugelj, R., and Hočever, F. (2007) Dom IRIS (Inteligentne rešitve in inovacije za samostojno življenje). Rehabilitacija, 6(1-2), pp. 101-104. 